\title{
Inteligentne sieci jako platforma umożliwiająca innowacyjną działalność przedsiębiorców w sektorze elektroenergetycznym - problematyka prawna
}

\section{Wprowadzenie}

W dobie dzisiejszego rozwoju gospodarczego energia elektryczna stanowi jeden z podstawowych nośników energii, umożliwiających rozwój technologiczny oraz stworzenie tzw. inteligentnego społeczeństwa opartego na wiedzy i informacji. Termin ten odnosi się do społeczeństwa, w którym większość najważniejszych sfer działalności człowieka, w tym przede wszystkim działalność gospodarcza, opartych jest na zaawansowanych technologiach informatycznych (IT). Warto jednak wskazać, że możliwość rozwoju gospodarczego oraz realizacji wizji "cyfrowej" gospodarki w dużej mierze uzależniona jest od wykorzystania innowacyjnych rozwiązań w każdej dziedzinie życia społeczno-gospodarczego. Postulat ten należy zrealizować zwłaszcza w sektorze wytwarzania i dostarczania energii elektrycznej, na dostępności której oparte są wszystkie inne technologie IT, wykorzystywane zarówno w sferze społecznej, jak i gospodarczej.

W przeważającej części działań gospodarczych konieczność rozwoju oraz wdrażania innowacyjnych rozwiązań technologicznych determinowana jest przez konieczność budowania przewagi konkurencyjnej, stanowiącej odpowiedź na procesy zachodzące na danym rynku. Jednakże sektor elektroenergetyczny należy do tych sektorów 
infrastruktury sieciowej, w których konkurencja nie może rozwijać się w sposób naturalny, a natężenie regulacji sektorowej jako przejawu szczególnej interwencji państwa w gospodarkę jest bardzo wysokie ${ }^{1}$. W związku z powyższym regulacja sektorowa, postrzegana jako interwencja państwa w decyzje ekonomiczne przedsiębiorców, powinna przede wszystkim koncentrować się na problemie wpływu poszczególnych instrumentów regulacyjnych na stymulowanie innowacyjnych działań w sektorze elektroenergetycznym. Do takich działań należy zaliczyć koncepcję wprowadzenia inteligentnego opomiarowania i inteligentnych sieci w elektroenergetyce. Jednakże ze względu na zaangażowanie $w$ inne projekty oraz dość wysokie koszty inwestycyjne przedsiębiorstwa energetyczne ${ }^{2}$ odpowiedzialne za rozwój sieci elektroenergetycznych ograniczyły się jedynie do wdrażania pilotażowych programów tego typu. W związku z tym warto zadać pytanie, czym są inteligentne sieci energetyczne, oraz wskazać na ich potencjalne uwarunkowania techniczne i ekonomiczne, umożliwiające zwiększanie konkurencyjności oraz innowacyjności sektora. Aby odpowiedzieć na te pytania, należy przede wszystkim dokonać przeglądu obowiązującego stanu prawnego wraz $z$ analizą działań podejmowanych $w$ tym zakresie przez organy administracji właściwe w sprawach elektroenergetyki. Szczególnie doniosłe będą tu akty prawa unijnego wskazujące cele i zasady funkcjonowania systemu elektroenergetycznego, do których powinny dążyć poszczególne państwa członkowskie UE. Warto też się zastanowić, czy polski ustawodawca, kształtując instrumenty regulacji sektorowej, zadbał o to, aby w odpowiedni sposób stymulowały one rozwój innowacyjnych rozwiązań dotyczących sieci. W kontekście wprowadzanych instrumentów regulacji sektorowej warto też wskazać na pojawiające się perspektywy inwestycyjne dla najbardziej innowacyjnych przedsiębiorców, zdolnych wykorzystać pojawiające się szanse. Po dokonaniu owego przeglądu warto również ocenić, czy polskie regulacje prawne pozytywnie wpływają na rozwój inteligentnych sieci elektroenergetycznych oraz wskazać działania, w których ich potencjał nie został do końca wykorzystany.

${ }^{1}$ T. Długosz, Funkcja regulacyjna, w: Publiczne prawo gospodarcze, seria System prawa administracyjnego, pod red. R. Hausera, Z. Niewiadomskiego, A. Wróbla, t. 8A, Warszawa 2013, s. 697-707.

2 Autor w niniejszym opracowaniu świadomie posługuje się ustawowym pojęciem "przedsiębiorstwa energetycznego", definiowanym w art. 3 pkt 12 Ustawy z dnia 10 IV 1997 r. Prawo energetyczne (tekst jedn. Dz.U. 2012, poz. 1059 ze zm., dalej „u.p.e.”), czyli pojęciem przedsiębiorstwa w znaczeniu podmiotowym. 


\section{Inteligentne sieci elektroenergetyczne jako przykład innowacji sektorowej}

Inteligentne sieci energetyczne (ISE) (ang. smart grids) to sieci teleinformatyczno-energetyczne, które są w stanie efektywnie integrować zachowania poszczególnych użytkowników Krajowego Systemu Elektroenergetycznego (KSE), tj. wytwórców, operatorów systemów: przesyłowego (OSP) i dystrybucyjnego (OSD) ${ }^{3}$, a także odbiorców oraz prosumentów ${ }^{4}$. Urządzenia te charakteryzują się pewnym pierwiastkiem inteligencji i z tego powodu nie tworzą wyłącznie systemu wzajemnie połączonych sieci zdolnych do jednokierunkowego transportu energii od wytwórcy do odbiorców ${ }^{5}$. Urządzenia te tworzą swego rodzaju platformę dwukierunkowej komunikacji cyfrowej między przedsiębiorstwem energetycznym a odbiorca, umożliwiającą łatwe zarządzanie ruchem sieciowym oraz efektywne wykorzystywanie wytworzonej energii elektrycznej. Ponadto nieodłącznym elementem będącym częścią ISE jest inteligentne opomiarowanie (ang. smart metering), a więc urządzenia pozwalające na interaktywny pomiar oraz gromadzenie i analizowanie informacji o aktualnie pobieranej energii. Tak więc inteligentne urządzenie pomiarowe to nie tylko sam licznik (układ pomiarowo-rozliczeniowy), ale także zestaw wzajemnie połączonych urządzeń teleinformatycznych umożliwiających zdalną komunikację między tym licznikiem a mobilnymi urządzeniami odbiorcy lub przedsiębiorstwa energetycznego. Możliwość zastosowania zestawu takich urządzeń tworzy zintegrowany inteligentny system pomiarowy (ang. Advanced Metering Infrastructure AMI), umożliwiający zbieranie, przechowywanie i przetwarzanie danych pomiarowych dotyczących zużywanej energii elektrycznej, a także stosowanie przez odbiorcę odpowiednich informacji lub komend dotyczących zarządzania aktualnym zużyciem energii przez danego odbiorcę $^{6}$. Abstrahując od konieczności zabezpieczenia wrażliwych

${ }^{3}$ Zob. F.M. Elżanowski, Smart grids i smart metering w procesie inwestycyjnym, w: Energetyka i ochrona środowiska w procesie inwestycyjnym, pod red. M. Cherki i in., Warszawa 2010, s. 18-19.

${ }^{4}$ Prosument - odbiorca końcowy wytwarzający energię elektryczną wyłącznie z odnawialnych źródeł energii w mikroinstalacji w celu jej zużycia na potrzeby własne. Podmiot ten nie może także wykonywać innej działalności gospodarczej wykonywanej przez przedsiębiorstwa energetyczne.

${ }^{5}$ Por. definicję pojęcia "sieci" zawartą w art. 3 pkt 11 u.p.e.

${ }^{6}$ Por. Stanowisko Prezesa Urzędu Regulacji Energetyki (URE) w sprawie koncepcji dotyczącej modelu rynku opomiarowania w Polsce, ze szczególnym uwzględnieniem wymagań wobec Operatora Informacji Pomiarowej. 
danych dotyczących odbiorcy ${ }^{7}$, należy wskazać, że urządzenia takie są $\mathrm{w}$ stanie reagować $\mathrm{w}$ czasie rzeczywistym na sygnały kierowane do nich przez przedsiębiorstwa energetyczne lub odbiorcę. Sygnały te mogą zatem stanowić swoistą reakcję tych podmiotów na aktualną sytuację rynkową. Tym samym wdrożenie inteligentnych systemów pomiarowych stanowi podstawę stworzenia inteligentnej sieci, a więc takiej, która wykorzystując technologie telekomunikacyjne i telemetryczne, gromadzi informacje o uczestnikach rynku energii elektrycznej w celu zachowania bezpieczeństwa dostaw oraz osiągnięcia wyższej efektywności energetycznej. Ponadto wykorzystanie wskazanych powyżej nowoczesnych technologii oraz innowacyjnych urządzeń do sterowania i zabezpieczenia sieci będzie zasadniczym i innowacyjnym przełomem w zakresie zasad funkcjonowania systemu elektroenergetycznego, a także warunków rozwoju konkurencji w tym sektorze.

\section{Podstawy prawne wdrażania inteligentnych sieci elektroenergetycznych}

Wskazane powyżej zagadnienia są przedmiotem zainteresowania licznych aktów prawa europejskiego, takich jak chociażby dyrektywy wchodzace w skład III pakietu liberalizacyjnego ${ }^{8}$. I tak, zgodnie z pkt 27 Preambuły do Dyrektywy Parlamentu Europejskiego i Rady 2009/72/WE z dnia 13 lipca 2009 r. dotyczącej wspólnych zasad rynku wewnętrznego energii elektrycznej i uchylającej dyrektywę 2003/54/ $\mathrm{WE}^{9}$ (dyrektywa 2009/72/WE), państwa członkowskie powinny zachęcać krajowe podmioty do modernizacji sieci dystrybucyjnych poprzez wprowadzanie sieci inteligentnych, które należy budować w sposób zachęcający do zdecentralizowanego wytwarzania energii oraz do efektywności energetycznej. Następnie w art. 3 ust. 11 dyrektywy 2009/72/WE prawodawca unijny stwierdza, że państwa członkowskie powinny zdecydowanie zalecać przedsiębiorstwom energetycznym

${ }^{7}$ N. Rysz, Ochrona danych w funkcjonowaniu inteligentnych sieci (smart grid), w: Regulacja - innowacja w sektorze energetycznym, pod red. A. Walaszek-Pyzioł, Warszawa 2013, s. 517-531.

${ }^{8}$ Szerszego przeglądu aktów europejskich odnoszących się do zagadnienia inteligentnych sieci dokonano w: M. Swora, Inteligentne opomiarowanie jako przykład rozwiqzania innowacyjnego w świetle nowej dyrektywy o efektywności, w: Regulacja - innowacja..., s. $473-484$.

${ }^{9}$ Dz.Urz. UE L 211 z 14 VIII 2009 r., s. 55. 
optymalizację wykorzystania energii elektrycznej, m.in. poprzez wprowadzenie inteligentnych systemów pomiarowych lub inteligentnych sieci. Doprecyzowaniem wskazanego powyżej przepisu jest Załącznik 1 do dyrektywy 2009/72/WE. Zgodnie z treścią pkt 2 tego Załącznika państwa członkowskie zapewniają wdrożenie inteligentnych systemów pomiarowych pozwalających na aktywne uczestnictwo konsumentów w rynku dostaw energii. Jednocześnie prawodawca unijny zastrzega, że kompleksowe wdrożenie systemów pomiarowych może być uzależnione od przeprowadzenia odpowiedniej oceny ekonomicznej takiego przedsięwzięcia. Luz decyzyjny w tej sprawie pozostawiono państwom członkowskim, które zostały zobowiązane do dokonania takiej oceny do dnia 3 września 2012 r. Jeżeli ocena taka wypadła pozytywnie, to dane państwo członkowskie powinno wyposażyć przynajmniej $80 \%$ konsumentów w inteligentne systemy pomiarowe do końca 2020 r. Tak więc na kanwie dyrektywy 2009/72/WE wyraźnie zarysowuje się kierunek działań prawodawcy europejskiego. Punktem wyjścia są przepisy Preambuły, w których dostrzeżono oraz podkreślono potrzebę inwestycji w ISE. Następnie w przepisach dotyczących ogólnych zasad organizacji sektora elektroenergetycznego niezobowiązująco stwierdzono, że państwa członkowskie powinny wspierać zarówno działania w kierunku wdrażania inteligentnych sieci, jak i inteligentnego opomiarowania, poprzez zalecanie takich rozwiązań krajowym podmiotom uczestniczącym w rynku energii elektrycznej. Ostatecznie w Załączniku 1 prawodawca unijny wskazał podstawę prawną zobowiązującą niektóre państwa członkowskie, w ramach swego rodzaju "wzmożonej współpracy”, do wdrożenia inteligentnych systemów pomiarowych stanowiących ważny, choć tylko jeden z elementów systemu ISE. Wskazany powyżej kierunek działań prawodawcy unijnego, koncentrujący się wyłącznie na potrzebie wdrożenia inteligentnych systemów pomiarowych, ma przede wszystkim doprowadzić do bardziej racjonalnego wykorzystywania energii elektrycznej przez odbiorców końcowych.

Jednocześnie zagadnienie bardziej oszczędnego i zrównoważonego zużycia energii elektrycznej jest regulowane także przepisami Dyrektywy Parlamentu Europejskiego i Rady 2012/27/WE z dnia 25 października 2012 r. w sprawie efektywności energetycznej, zmiany dyrektywy 2009/125/WE i 2010/30/UE oraz uchylenia dyrektywy 2004/8/WE i $2006 / 32 / W^{10}$ (dyrektywa 2012/27/WE). W pkt 32 i 33 Preambuły

${ }^{10}$ Dz.Urz. UE L 315 z 14 XI 2012 r., s. 1. 
dyrektywy 2012/27/WE podkreślono przede wszystkim, że pomimo dostrzeżonej w dyrektywie 2009/72/WE potrzeby wdrożenia innowacyjnych rozwiązań w zakresie ISE wpływ jej przepisów na oszczędność energii jest ograniczony. Dlatego w dyrektywie 2012/27/WE ponownie podkreślono, że jedną z możliwości służących poprawie efektywności energetycznej jest umożliwienie odbiorcom szybkiego dostępu do rzeczywistych danych pomiarowych, zapewniających skuteczną samokontrolę bieżącego zużyciu energii. Następnie w art. 10 ust. 2 dyrektywy 2012/27/WE wskazano, że jeżeli dane państwo członkowskie zdecydowało się na wdrożenie inteligentnego opomiarowania, to powinno ono zapewniać zarówno dostęp do aktualnych informacji pomiarowych przekazywanych w czasie rzeczywistym, jak i dostęp do szczegółowych danych o historycznym zużyciu energii. Dane te powinny być dostępne przez Internet lub na wyświetlaczu urządzenia oraz uwzględniać informacje za co najmniej trzy poprzednie lata. Jeżeli okres ten był krótszy, informacje powinny być gromadzone od dnia rozpoczęcia umowy. Niemniej, zgodnie z art. 10 ust. 1 dyrektywy 2012/27/WE, nawet jeżeli nie zdecydowano się na wdrożenie inteligentnych liczników, państwa członkowskie zobowiązane są do 31 grudnia 2014 r. zapewnić, by informacje o rozliczeniach były oparte na rzeczywistym zużyciu energii elektrycznej, a nie na zużyciu szacunkowym czy stawce ryczałtowej. Prawodawca unijny ponownie uzależnił konieczność wprowadzenia tych zmian od możliwości technicznych oraz ekonomicznej opłacalności. Jednocześnie wskazał, że obowiązek ten można zrealizować poprzez umożliwienie dokonywania odczytów przez samych odbiorców końcowych, które to dane będą bezpośrednio przekazywane przedsiębiorstwu energetycznemu. Ponadto, jeżeli nie zdecydowano się na zamontowanie inteligentnych liczników, to zgodnie z art. 10 ust. 3 dyrektywy 2012/27/ WE państwa członkowskie są zobowiązane wprowadzić rozwiązania umożliwiające dostęp do historycznych danych o rozliczeniach oraz zużyciu energii elektrycznej przez danego odbiorcę końcowego, które to dane obligatoryjnie mają być udostępniane samemu odbiorcy bądź wskazanemu przez niego przedsiębiorstwu energetycznemu. Odbiorca końcowy powinien też mieć możliwość dostępu do elektronicznej formy informacji o rozliczeniach i rachunkach oraz otrzymywać jasne i zrozumiałe wyjaśnienia, w jaki sposób wyliczono ich rachunek, w szczególności gdy rachunki te nie są oparte na rzeczywistym zużyciu energii elektrycznej. Omawiana dyrektywa nie wprowadziła zatem powszechnego obowiązku instalowania inteligentnych systemów pomiarowych, 
jednakże wskazano państwom członkowskim potrzebę wprowadzenia rozwiązań umożliwiających zbieranie i przetwarzanie danych pomiarowych o rzeczywistym zużyciu energii przez danego odbiorcę końcowego. Ponadto zaznaczono, że uzyskiwanie tych informacji powinno być również możliwe w formie elektronicznej, niezależnie od tego, czy zdecydowano się na wprowadzenie inteligentnych systemów pomiarowych, czy z przyczyn ekonomicznej oceny przesunięto tę decyzję w czasie. Na kanwie dyrektywy 2012/27/WE wyraźnie zarysowuje się zatem dążenie do wprowadzenia obowiązkowego rozliczania zużycia energii w czasie rzeczywistym, tak aby odbiorca końcowy na podstawie dostępnych informacji mógł bardziej efektywnie zarządzać zużywaną przez siebie energią elektryczną.

Podsumowując dotychczasowe rozważania dotyczące prawodawstwa europejskiego, warto wskazać na zaangażowanie Polski w proces wdrażania inteligentnych systemów pomiarowych. Ostatecznie, w dokumencie „Informacja dotycząca zasadności wprowadzenia inteligentnych form pomiaru zużycia energii elektrycznej w Polsce"11 stwierdzono, że zdaniem strony polskiej wdrożenie inteligentnych systemów pomiarowych jest nie tylko procesem koniecznym i opłacalnym, ale także nieuchronnym, gdyż przemawiają za tym zarówno przesłanki faktyczne, jak i względy formalnoprawne. Ponadto w dokonanej przez ministra gospodarki w kwietniu 2013 r. „Analizie skutków społeczno-gospodarczych wdrożenia inteligentnego opomiarowania"12 potwierdzono liczne korzyści płynące z rozpowszechniania inteligentnych systemów pomiarowych. Tym samym strona polska zobowiązała się nie tylko do dokonywania rozliczeń opartych na rzeczywistym zużyciu energii, czego wymaga dyrektywa 2012/27/WE, ale także do pełnego wdrożenia przepisów dyrektywy 2009/72/WE, w tym również pkt 2 Załącznika 1 nakładającego obowiązek wyposażenia 80\% konsumentów $\mathrm{w}$ inteligentne systemy pomiarowe do $2020 \mathrm{r}^{13}$ Pomimo to aktualnie

${ }^{11}$ Zob. dokument zawarty na stronach internetowych Ministerstwa Gospodarki, http://www.mg.gov.pl/files/upload/18385/Informacja\%20dotycz $\%$ C4\%85ca\%20zasadno $\%$ C5\%9Bci\%20wprowadzenia $\% 20$ inteligentnych $\% 20$ form $\% 20$ pomiaru $\% 20 z u \% C 5 \% B-$ Cycia\%20energii\%20elektrycznej\%20w\%20Polsce.pdf (dostęp: 4 XII 2015).

${ }_{12}$ Zob. dokument zawarty na stronach internetowych Ministerstwa Gospodarki, http://www.mg.gov.pl/files/upload/18385/Analiza_skutkow_spoleczno-gospodarczych. pdf (dostęp: 4 XII 2015).

${ }^{13}$ W tym aspekcie warto wskazać, że 20 XII 2012 r. Komisja Europejska wniosła skargę do Trybunału Sprawiedliwości Unii Europejskiej (sprawa sygn. C-598/12), zarzucając Rzeczypospolitej Polskiej brak implementacji do ustawodawstwa krajowego przepisów 
obowiązująca u.p.e. nie zawiera przepisów prawnych bezpośrednio nakazujących przedsiębiorstwom energetycznym wdrażanie inteligentnych systemów sieciowych. Polski ustawodawca, przyjmując w art. 9c ust. 5a u.p.e. przepisy dotyczące ISE, ograniczył się jedynie do wskazania, że OSD, instalując u odbiorców końcowych liczniki zdalnego odczytu, są obowiązani chronić dane pomiarowe dotyczące tych odbiorców na zasadach określonych w Ustawie z dnia 29 sierpnia 1997 r. o ochronie danych osobowych ${ }^{14}$. Ponadto, zgodnie z art. 16 ust. 7 pkt 4 u.p.e., OSP i OSD, sporządzając plany rozwoju sieci, powinni uwzględnić w nich przedsięwzięcia w zakresie pozyskiwania, transmisji oraz przetwarzania danych pomiarowych z licznika zdalnego odczytu. Jednocześnie w art. 9c ust. $5 b$ u.p.e. ustawodawca zdefiniował pojęcie licznika zdalnego odczytu, przez który należy rozumieć zespół urządzeń służących do pozyskiwania danych pomiarowych umożliwiających dwustronną komunikację z systemem teleinformatycznym. Niemniej wydaje się, że legalna definicja pojęcia licznika zdalnego odczytu w pełni odpowiada wskazywanym w paragrafie pierwszym niniejszego opracowania pojęciu inteligentnych systemów pomiarowych, którymi posługuje się prezes URE. Nie wdając się jednak w rozważania terminologiczne, należy stwierdzić, że pomimo dość powierzchownego potraktowania tego zagadnienia przez ustawodawcę problem ten w coraz większym stopniu staje się też przedmiotem zainteresowania organów administracji rządowej właściwych w sprawach energetyki. Dobrym przykładem potwierdzającym tę tezę jest charakterystyka wyzwań i celów stojących przed sektorem energetycznym, określona $\mathrm{w}$ „Projekcie polityki energetycznej Polski do 2050 r." przygotowanym przez ministra gospodarki w 2015 r. Abstrahując od problemu prawnej kwalifikacji tego dokumentu pośród źródeł prawa ${ }^{15}$, należy stwierdzić, że dokument ten przedstawia perspektywy rozwoju polskiego sektora energetycznego. W tym kontekście

dyrektywy 2009/72/WE, w tym w szczególności przepisów zawartych w Załączniku 1 pkt 2 dyrektywy 2009/72/WE. Ostatecznie, w efekcie przyjęcia przez Polskę Ustawy z dnia 26 lipca 2013 r. o zmianie ustawy - Prawo energetyczne oraz niektórych innych ustaw (Dz.U. 2013, poz. 984) - tzw. „małego trójpaku” - Komisja Europejska cofnęła skargę, a sprawa została wykreślona z rejestru Trybunału. Zob. http://curia.europa. eu/juris/document/document.jsf?text $=\&$ docid $=145861 \&$ pageIndex $=0 \&$ doclang $=P L \&$ mode $=1$ st \& dir $=\& o c c=$ first \& part $=1 \&$ cid $=407570$ (dostęp: 4 XII 2015).

14 Tekst jedn. Dz.U. 2002 Nr 101, poz. 926 ze zm.

${ }^{15}$ Zob. M. Trupkiewicz, Zadania Prezesa URE a polityka energetyczna państwa, "Przegląd Prawniczy Europejskiego Stowarzyszenia Studentów Prawa ELSA Poland”, Warszawa 2014, s. 159-173. 
warto wskazać, że jednym z głównych celów polityki energetycznej jest konieczność rozwoju inteligentnych sieci energetycznych. Wśród priorytetowych kierunków interwencji minister gospodarki opisał działania dotyczące inteligentnych sieci energetycznych ${ }^{16}$ oraz energetyki prosumenckiej ${ }^{17}$, które to bezpośrednio odnoszą się do omawianych w niniejszym opracowaniu zagadnień. Projektodawca zaproponował również scenariuszowe podejście do perspektywy rozwoju sektora energetycznego w Polsce. Oznacza to, że określono trzy prawdopodobne scenariusze rozwoju sektora energetycznego w naszym kraju, zaś do realizacji zostanie przeznaczony ten spośród nich, który w najlepszy sposób odda uwarunkowania globalne, założenia polityki UE oraz kierunki zmian technologicznych. Jednakże projektodawca zaproponował też pakiet wspólnych założeń dla wszystkich proponowanych scenariuszy rozwoju, który to pakiet zakłada w szczególności konieczność inwestycji w sieci inteligentne. Wyrażono również oczekiwanie, że w perspektywie do 2050 r. wszystkie sieci będą miały charakter inteligentny ${ }^{18}$, co niewątpliwie stanowi duże wyzwanie stawiane przed przedsiębiorstwami energetycznymi. Inicjatywę w zakresie ISE podjął również prezes URE, który jako organ regulacyjny w sektorze elektroenergetyki może skutecznie wpływać na ich rozwój. Prezes URE wypracował liczne stanowiska ${ }^{19} \mathrm{~W}$ sprawie promowania inteligentnych systemów pomiarowych. Przede wszystkim zwrócono w nich uwagę na konieczność zapewnienia interoperacyjności wszystkich współpracujących ze sobą elementów urządzeń tworzących tzw. Smart Grid oraz zakres funkcjonowania interfejsów komunikacyjnych systemów AMI. Zaproponowano również postulowany model dotyczący zarządzania informacjami pomiarowymi oparty na konieczności powołania specjalnego podmiotu, jakim powinien być Operator Informacji Pomiarowej. Po dokonaniu przeglądu przepisów prawa europejskiego oraz krajowego odnoszących się do konieczności inwestycji infrastrukturalnych oraz wdrożenia ISE należy zastanowić się, jakie potencjalne korzyści mogą one przynieść dla sektora elektroenergetycznego, a w dalszej perspektywie dla całej polskiej gospodarki.

${ }^{16}$ Projekt "Polityka energetyczna Polski do 2050 r.", s. 12 i 28-29, http://bip.mg.gov. pl/node/24670 (dostęp: 7 XII 2015).

${ }^{17}$ Ibidem, s. 11.

${ }^{18}$ Ibidem, s. 32-33.

${ }^{19}$ Przegląd Stanowisk Prezesa URE w sprawie inteligentnych sieci elektroenergetycznych, http://ise.ure.gov.pl/ise/stanowiska-regulatora (dostęp: 7 XII 2015). 


\section{Przykłady innowacyjnych rozwiązań opartych na wykorzystaniu inteligentnych sieci elektroenergetycznych}

Rozważając zagadnienia związane z innowacyjnym charakterem wdrożenia inteligentnych sieci elektroenergetycznych oraz inteligentnych systemów pomiarowych, nie sposób pominąć praktycznego aspektu proponowanych rozwiązań. Nie ulega wątpliwości, że wymiana urządzeń elektroenergetycznych na te charakteryzujące się cechą "inteligencji” stworzy nowe pola ich eksploatacji oraz wykreuje nowe perspektywy inwestycyjne umożliwiające budowanie przewagi konkurencyjnej między przedsiębiorcami rywalizującymi w sektorze elektroenergetycznym. Ze względu na ograniczoną objętość niniejszego opracowania w dalszej jego części wskazano jedynie kilka potencjalnych możliwości wykorzystania ISE.

Jednym z najważniejszych wyzwań stojących przed cała gospodarką jest przestrzeganie restrykcyjnej polityki klimatyczno-energetycznej UE do $2020 \mathrm{r}$. W skrótowym ujęciu cele te można przedstawić w trzech hasłach: (1) ograniczenie emisji gazów cieplarnianych o 20\%, (2) 20-procentowy udział OZE w miksie energetycznym oraz (3) zwiększenie efektywności energetycznej o 20\%. Następnie założenia polityki klimatyczno-energetycznej UE zostały doprecyzowane i uzgodnione w Konkluzjach Rady Europejskiej z 23 i 24 października 2014 r. (EUCO $169 / 14)^{20} \mathrm{w}$ perspektywie do $2030 \mathrm{r}$. W dokumencie przewidziano m.in. cele UE w zakresie zmniejszenia emisji gazów cieplarnianych o co najmniej 40\% w porównaniu z poziomem z 1990 r., zwiększenie do co najmniej $27 \%$ udziału energii ze źródeł odnawialnych w energii zużywanej w UE, a także uzyskanie efektywności energetycznej na poziomie $27 \%$, a nawet $30 \% \mathrm{w}$ porównaniu z prognozami zużycia tejże energii w 2030 r. Wydaje się, że te ambitne założenia w dużej mierze można zrealizować dzięki inwestycjom w ISE. Wykorzystanie urządzeń sieciowych typu "smart" pozwoli zmniejszyć emisję gazów cieplarnianych dzięki zastąpieniu najstarszych i wysokoemisyjnych bloków konwencjonalnych rozproszoną energetyką wykorzystującą odnawialne źródła energii. Rozwój ISE jest warunkiem sine qua non sprawnego funkcjonowania dwukierunkowych przepływów energii między mikroinstalacjami prosumenckimi a resztą KSE. W tym aspekcie warto chociażby

${ }^{20}$ Por. konkluzje oraz cele polityki klimatyczno-energetycznej do 2030 r. przyjęte przez Radę Europejska, http://www.consilium.europa.eu/uedocs/cms_data/docs/ pressdata/PL/ec/145432.pdf (dostęp: 7 XII 2015). 
wskazać na postanowienia art. 41 ust. 14 Ustawy z dnia 20 lutego 2015 r. o odnawialnych źródłach energii ${ }^{21}$ stwierdzające, że nowy mechanizm wsparcia prosumenckich instalacji OZE ma być oparty na rzeczywistych wskazaniach urządzeń pomiarowo-rozliczeniowych. W innych przepisach u.o.z.e. również odwołuje się do konieczności stosowania urządzeń pomiarowo-rozliczeniowych wskazujących na rzeczywista ilość energii elektrycznej dostarczanej do lub pobieranej z sieci przez daną instalację OZE. Ponadto $w$ art. 61 u.o.z.e. upoważniono ministra właściwego do spraw gospodarki do określenia w drodze rozporządzenia m.in. wymagań dotyczących pomiarów, rejestracji i sposobu obliczania ilości energii wytwarzanych w instalacjach OZE. Wskazane przez ministra rozwiązania techniczne niewątpliwie powinny opierać się na konieczności zastosowania inteligentnych systemów pomiarowych. Wzrost udziału energii ze źródeł odnawialnych, oprócz idealistycznych celów związanych z ochroną klimatu, ma też przełożenie na efekty czysto rynkowe. Inwestycje w zakresie instalacji wytwarzających energię elektryczną ze źródeł odnawialnych oraz urządzeń towarzyszących sprzyjaja rozwojowi technologicznemu, know-how oraz oferowanych dóbr i usług, które w konsekwencji mogą być transferowane na pozostałe rynki światowe. $\mathrm{W}$ tym aspekcie inwestycje $\mathrm{w}$ automatykę sieci oraz urządzenia teleinformatyczne mogą stanowić pozytywny bodziec nie tylko dla realizacji celów elektroenergetyki i ochrony klimatu, ale też dla całej polskiej oraz unijnej gospodarki, mogącej wyspecjalizować się $\mathrm{w}$ zakresie produkcji dóbr i usług powiązanych $\mathrm{z}$ wytwarzaniem energii z OZE.

Inwestycje $\mathrm{w}$ inteligentne urządzenia pomiarowe ułatwią też realizację obowiązków dotyczących efektywności energetycznej. Dzięki tym urządzeniom każdy odbiorca energii uzyska pakiet informacji dotyczących aktualnie zużywanej przez siebie energii, co powinno skłonić go do bardziej racjonalnego i efektywnego zarządzania nią. Natomiast funkcja dwustronnej komunikacji za pośrednictwem odpowiedniej aplikacji internetowej w telefonie komórkowym bądź tablecie umożliwi odłączanie albo redukowanie zbędnych dla odbiorcy procesów. Warto zatem jeszcze raz podkreślić, że inwestycje w inteligentne sieci oraz inteligentne systemy pomiarowe w znacznym stopniu wpłyną na rozwój branży OZE, która pośrednio bądź bezpośrednio przyczynia się do realizacji celów polityki klimatyczno-energetycznej UE. Natomiast

${ }^{21}$ Dz.U. 2015, poz. 478, dalej „u.o.z.e.”. 
w odniesieniu do odbiorców końcowych inwestycje w inteligentne systemy pomiarowe stanowia jeden z podstawowych elementów realizacji celów dotyczących efektywności energetycznej.

Kolejnym pozytywnym aspektem wprowadzenia ISE powinien być wzrost konkurencji na rynku energii elektrycznej, który to obecnie zdominowany jest przez zasiedziałe przedsiębiorstwa energetyczne. Poszerzenie zakresu konkurencji w sektorze infrastruktury sieciowej stanowi podstawowy cel tzw. regulacji prokonkurencyjnej ${ }^{22}$. Jednakże konkurencja w tym sektorze może rozwijać się także dzięki wdrażaniu innowacyjnych rozwiązań, jakimi są ISE. W tym aspekcie wydaje się, że wdrażanie innowacji sieciowych można uznać za swego rodzaju instrument realizacji celów prokonkurencyjnej regulacji sektora elektroenergetycznego. Działania w tym zakresie pozwolą ukształtować nowy segment rynku charakteryzujący się koniecznością realizowania przez przedsiębiorstwa energetyczne nowych usług. Dzięki funkcji dwustronnej komunikacji oraz rzeczywistego pomiaru zużytej energii przedsiębiorstwa te będą musiały dopasować się do nowych potrzeb odbiorców, mających ułatwiony i zdalny wpływ na zarządzanie wykorzystywana przez siebie energią. Innowacyjny przedsiębiorca, tworząc odpowiednie aplikacje kompatybilne z urządzeniami sieciowymi i pomiarowymi, może wprowadzić nową jakość na rynku elektroenergetycznym. Uruchamiając nowe interaktywne usługi ${ }^{23}$ służące lepszemu zarządzaniu zużywaną energią lub produkty bazujące na inteligentnej sieci domowej (ang. home area network - HAN), podmiot taki może skutecznie konkurować z zasiedziałymi sprzedawcami energii, oferując unikatowy pakiet usług po cenie pozwalającej osiągnąć spodziewany zysk. Dotychczasowi sprzedawcy energii nie oferują na powszechną skalę podobnych usług, co niewątpliwie stwarza przestrzeń do budowania przewagi konkurencyjnej przez innowacyjny podmiot inwestujący w ISE. Ponadto poszerzanie zakresu konkurencji w tym

22 Szerzej zob. T. Skoczny, Ochrona konkurencji a prokonkurencyjna regulacja sektorowa, „Problemy Zarządzania” 2004, nr 3, s. 15; idem, Regulacja prokonkurencyjna w sektorach infrastrukturalnych, w: Prawo konkurencji, seria System Prawa Prywatnego, pod red. M. Kępińskiego, t. 15, s. 1354-1372; M. Szydło, Regulacja sektorów infrastrukturalnych jako rodzaj funkcji państwa wobec gospodarki, Warszawa 2005; E. Kosiński, Regulacja prokonkurencyjna nowa funkcja państwa? Rozważania na przykładzie regulacji sektora elektroenergetycznego Unii Europejskiej, w: Funkcje współczesnej administracji gospodarczej. Księga dedykowana Profesor Teresie Rabskiej, pod red. B. Popowskiej, Poznań 2006, s. 183-210.

${ }^{23}$ Zob. R. Zajdler, M. Gałczyński, Smartsument - nowoczesny konsument w inteligentnych miastach przyszłości, Warszawa 2014. 
sektorze umożliwi stopniowe uwalnianie rynku spod reżimu administracyjnoprawnej regulacji sektorowej, a w szczególności doprowadzi do uwolnienia zatwierdzanych przez prezesa URE taryf dla odbiorców końcowych w gospodarstwach domowych. Jeżeli na rynku pojawią się nowe podmioty, chociażby te z sektora telekomunikacyjnego, chcące sprzedawać energię wraz z innowacyjnymi usługami typu HAN, to przedsiębiorstwa energetyczne także będą musiały konkurować ze sobą zróżnicowanymi taryfami uwzględniającymi różne mechanizmy ich kalkulacji tak, aby jak najlepiej dopasować się do różnych wymagań odbiorców energii.

Wykorzystanie urządzeń teleinformatyczno-energetycznych pozytywnie wpłynie także na bezpieczeństwo energetyczne oraz bilansowanie $\mathrm{KSE}^{24}$. Na potrzeby niniejszego opracowania można przyjąć, że w założeniu tym chodzi o to, by w danym momencie w sieci było tyle energii, ile potrzebują odbiorcy. Innymi słowy, cały skomplikowany system wytwarzania i transportu energii sieciami przesyłowymi i dystrybucyjnymi musi zostać zrealizowany w momencie, gdy dany odbiorca jej potrzebuje, a wyhamowany w momencie niskiego popytu na nią. Zagrożenie niezbilansowania systemu elektroenergetycznego opartego na ISE oddala się z co najmniej dwóch powodów. Po pierwsze, inwestycje w inteligentne urządzenia sieciowe umożliwią rozwój prosumenckiej oraz odnawialnej energetyki rozproszonej, zastępującej najstarsze bloki konwencjonalne. Inwestycje takie nie tylko pozwola osiągnąć cele polityki klimatyczno-energetycznej UE, ale umożliwią także wytwarzanie energii ze źródeł odnawialnych, które znajdując się na terenie całego kraju, ograniczają potrzebę jej przesyłu. Energia ta będzie wytwarzana w źródłach generacji rozproszonej, która choć trudna w zarządzaniu poszczególnymi przepływami tejże energii, może jednak być skutecznie realizowana dzięki ISE ${ }^{25}$. Ponadto inteligentne sieci dadzą możliwość lepszego i bardziej ukierunkowanego zarządzania całą infrastrukturą sieciową, co będzie oznaczało jej większe bezpieczeństwo i tańszą eksploatację. Po drugie, wdrożenie inteligentnych urządzeń sieciowych i pomiarowych daje nowe narzędzia, których wykorzystanie minimalizuje zagrożenie niekontrolowanych przerw $\mathrm{w}$ dostawach energii. W szczególności chodzi tu o możliwość zastosowania odpowiednich mechanizmów zarządzania stroną

${ }^{24}$ Zob. F.M. Elżanowski, op. cit., s. 21.

${ }^{25}$ Zob. B.M. Buchholz, Z. Styczyński, Smart Grids - Fundamentals and Technologies in Electricity Networks, Heidelberg-New York-London 2014. 
popytowa, mających wymierny wpływ na konieczność bilansowania systemu elektroenergetycznego. Właściwość ta staje się niezwykle cenna zwłaszcza w chwili największego zapotrzebowania na tę energię lub w przypadku skrajnie wysokich temperatur uniemożliwiających skuteczne funkcjonowanie elektrowni konwencjonalnych. Przez mechanizmy te należy rozumieć procesy związane $\mathrm{z}$ „zarządzaniem odbiorem" (ang. demand side management - DSM), które to pojęcie definiowane jest przez prezesa URE jako zbiór środków oddziaływania na poziom odbioru leżący w gestii OSP, sprzedawców, a w określonych sytuacjach także OSD ${ }^{26}$.

Niejako lustrzanym odbiciem wskazanego powyżej mechanizmu jest proces "reakcji strony popytowej" (ang. demand side response - DSR), będącej odpowiedzią racjonalnych odbiorców na sygnały cenowe pochodzące $\mathrm{z}$ konkurencyjnego rynku bądź zobowiązania przyjęte w drodze stosunku kontraktowego ${ }^{27}$. Przystąpienie odbiorcy do programu w ramach DSR jest dobrowolne i podlega zasadzie swobody umów. Cały mechanizm polega na dobrowolnym przenoszeniu przez odbiorców swojego zapotrzebowania na energię poza okresy szczytowego jej zużycia, co jest niejako rekompensowane przez przedsiębiorstwo energetyczne w drodze ekwiwalentnych świadczeń pieniężnych. Wynikiem zastosowania powyższych mechanizmów jest powstanie tzw. negawatów, czyli zaoszczędzonych jednostek energii, które mogą być wykorzystane przez inne podmioty, takie jak huty czy zakłady produkcji w ruchu ciągłym, które ze względów technologicznych nie mogą pozwolić sobie na przerwy $w$ dostawach energii. Przepisy art. 11e u.p.e. oraz $\S 40$ Rozporządzenia Ministra Gospodarki z dnia 4 maja 2007 r. w sprawie szczegółowych warunków funkcjonowania systemu elektroenergetycznego ${ }^{28}$ przewidują możliwość czasowego przerwania dostaw energii na podstawie szczególnych przypadków określonych w tych przepisach. Jednakże możliwość kontraktowego ograniczenia poboru energii elektrycznej przez wybrany krąg jej odbiorców pozwoli stosować ten mechanizm na zdecydowanie większą skalę, zapewniającą kontrolowalną rezerwę mocy w postaci zaoszczędzonych

${ }^{26}$ Por. Stanowisko Prezesa URE w sprawie niezbędnych wymagań wobec wdrażanych przez OSD E inteligentnych systemów pomiarowo-rozliczeniowych z uwzględnieniem funkcji celu oraz proponowanych mechanizmów wsparcia przy postulowanym modelu rynku, s. 65.

${ }^{27}$ Ibidem, s. 65-66; zob. też F.M. Elżanowski, op. cit., s. 20.

${ }^{28}$ Dz.U. 2007 Nr 93, poz. 623. 
negawatów. Biorąc pod uwagę pulę korzyści osiągniętych przez obie strony, wskazane rozwiązanie wydaje się nie lada atrakcyjne. Przedsiębiorstwa energetyczne będą mogły zaoferować największym odbiorcom przemysłowym pracującym w ruchu ciągłym gwarancję dostarczania określonej ilości energii bez ryzyka ograniczeń w jej poborze, a odbiorcy prywatni lub biznesowi, redukując swoje zapotrzebowanie, będą mogli osiągać korzyści finansowe czy bonifikaty związane ze współpracą z przedstawicielami sektora energetycznego ${ }^{29}$. Możliwość zarządzania stroną popytową jest także niezwykle ważna, jeśli wziąć pod uwagę wydarzenia z sierpnia 2015 r. związane z koniecznością wprowadzenia tzw. „20. stopnia zasilania” i ograniczeń w poborze energii, w szczególności dotkliwych dla najbardziej energochłonnych sektorów gospodarki.

Innym przykładem związanym z zarządzaniem stroną popytową poprzez bodźce cenowe jest stosowanie cen czasu rzeczywistego (ang. real-time pricing), co jest możliwe dzięki wykorzystaniu inteligentnego opomiarowania, a w szczególności AMI i inteligentnej sieci domowej. Uczestnictwo w tym programie pozwoli odbiorcom końcowym nie tylko na zarządzanie zużywaną przez siebie energią w bardziej efektywny sposób - tak jak zostało to opisane wcześniej - ale również na zakup energii po cenie ustalanej godzinowo na danym rynku. Odbiorcy końcowi z odpowiednio dużym wyprzedzeniem będą informowani o cenach energii i dzięki temu będą mogli nabywać potrzebną im ilość energii po satysfakcjonujących ich cenach. W szczególności mechanizm ten będzie miał znaczenie dla konsumentów (w rozumieniu art. $22^{1}$ Kodeksu cywilnego) oraz małych i średnich przedsiębiorców, którzy dzięki dwustronnej komunikacji będą mogli ograniczyć koszty zużywanej energii, natomiast przedsiębiorstwom energetycznym umożliwi on zaoszczędzenie tej energii w godzinach największego jej zużycia. Jednakże korzystanie $z$ tego mechanizmu wymaga od podmiotów wzmożonej komunikacji oraz obserwacji zmieniających się cen. Wydaje się więc, że opisany powyżej mechanizm wraz z systematyczną informacją o cenach energii może być wdrażany jedynie przy wykorzystaniu odpowiednich usług telekomunikacyjnych, dzięki którym sprzedawcy energii będą mogli wprowadzić oferty przedpłacone, zbliżone do funkcjonujących obecnie w sieciach telefonii komórkowej.

\footnotetext{
${ }^{29}$ Por. M. Swora, op. cit., s. 481-483.
} 


\section{Podsumowanie}

Reasumując powyższe rozważania, należy stwierdzić, że realizacja wizji "cyfrowej gospodarki" będzie bardzo trudna do osiągnięcia bez wdrożenia innowacyjnych rozwiązań w sektorze elektroenergetycznym. Jednym z przykładów innowacyjności, mającym jednocześnie duży potencjał $\mathrm{w}$ tym zakresie, jest koncepcja inteligentnych sieci umożliwiających bardziej efektywne korzystanie z urządzeń teleinformatyczno-energetycznych. Urządzenia te będą stanowić platformę, na której tradycyjne przedsiębiorstwa energetyczne lub nowe podmioty z sektora telekomunikacyjnego będą mogły rozwijać innowacyjne usługi lub produkty energetyczne $w$ infrastrukturze sieciowej oraz związane z nimi aplikacje informacyjno-komunikacyjne, automatykę domową czy innowacyjne urządzenia techniczne. Syntetycznie przedstawione w niniejszym opracowaniu przykłady komercyjnego wykorzystania potencjału ISE wskazują, że inwestycje w tym zakresie zapewnią zarówno wzrost konkurencyjności, jak i realizację podstawowego zadania przedsiębiorstw energetycznych, jakim jest zapewnienie ciągłości dostaw energii oraz bezpieczeństwa energetycznego. Ponadto wymierne korzyści osiągną także odbiorcy końcowi energii elektrycznej (przedsiębiorcy i konsumenci), którzy dzięki wykorzystaniu mechanizmów zarządzania popytem będą mogli nie tylko ponosić koszty związane z pobieraniem energii, ale także uzyskiwać określone przychody związane $\mathrm{z}$ powstaniem tzw. negawatów. Wdrożenie każdego z innowacyjnych rozwiązań musi być poprzedzone skrupulatnymi badaniami rynku, stanowiącymi podstawę ekonomicznej analizy opłacalności tego typu inwestycji. Jednakże oprócz korzyści natury ekonomicznej wdrożenie urządzeń infrastruktury elektroenergetycznej typu „smart” może przynieść znaczący postęp w realizacji celów społecznej odpowiedzialności biznesu (ang. corporate social responsibility - CSR). Oszczędność energii oraz uwzględnienie aspektów środowiskowych i założeń polityki klimatyczno-energetycznej UE powinno stanowić silny impuls do inwestycji w ISE. W tym aspekcie znaczenie ma również zmieniające się społeczeństwo, które jest coraz bardziej świadome swojej roli jako aktywnego uczestnika rynku energetycznego.

Potrzebę wdrożenia powyższych mechanizmów powinien determinować rynek i konkurujący ze sobą przedsiębiorcy, lecz ze względu na to, że energetyka jest sektorem infrastruktury sieciowej, nie można pomijać znaczenia przepisów prawa, pełniących w tym zakresie funkcję 
regulacji sektorowej. Biorąc więc pod uwagę wskazane w niniejszym opracowaniu argumenty, należy stwierdzić, że ustawodawca, realizując zobowiązania unijne, powinien wprowadzić odpowiednie instrumenty regulacyjne, mające na celu zachęcenie do infrastrukturalnych inwestycji w ISE, które to w dalszej perspektywie pozwolą jeszcze bardziej zliberalizować i unowocześnić sektor energetyczny. W tym kontekście warto podkreślić, że przepisy przywołanych w niniejszym opracowaniu unijnych dyrektyw jedynie w ogólnych motywach uzasadniających ich przyjęcie wskazują na konieczność inwestycji w szerszy system, jakim są inteligentne sieci elektroenergetyczne. Dyrektywy, skupiając się na realizacji celów w sferze efektywności energetycznej, większy nacisk kładą na kwestie związane z koniecznością inwestowania w inteligentne systemy pomiarowe oraz zapewnienia kalkulacji zużytej energii na podstawie rzeczywistych wskazań urządzeń pomiarowych. W związku z tym należy zaznaczyć, że przepisy u.p.e., implementując przepisy dyrektywy 2009/72/WE, a w szczególności jej Załącznika 1, nie wprowadziły prawnego obowiązku wyposażania odbiorców końcowych $\mathrm{w}$ inteligentne systemy pomiarowe, ograniczając się jedynie do regulacji prawnych odnoszacych się do kwestii ochrony danych pomiarowych. Szersza regulacja dotycząca stosowania układów pomiarowych zawarta została w przepisach u.o.z.e., gdzie wskazuje się, że w systemy takie powinni być wyposażeni prosumenci oraz wytwórcy energii z instalacji OZE, co pozwoli skutecznie oszacować ilość rzeczywiście wytworzonej oraz pobranej energii. W związku z dość ograniczoną materią ustawową zawartą w prawie energetycznym działania w tym zakresie podjęły odpowiedzialne za energetykę organy administracji rządowej. Minister właściwy do spraw gospodarki w projekcie „Polityka energetyczna Polski do 2050 r." stwierdził, że wszystkie sieci w KSE powinny być inteligentne do tej właśnie daty. Ponadto w wydanych przez Ministerstwo Gospodarki dokumentach zawarte są liczne analizy i interpretacje wskazujące na konieczność przeprowadzenia inwestycji w ISE, a w szczególności $\mathrm{w}$ inteligentne systemy pomiarowe. Swoją aktywność w tym zakresie zaznaczył też prezes URE, wydając kilka kluczowych dla sektora elektroenergetycznego stanowisk w sprawie konieczności zapewnienia neutralności i interoperacyjności technologicznej urządzeń oraz postulowanego modelu rynku opartego na inteligentnych systemach elektroenergetycznych. Ostatnie działania prezesa URE zawieszające niektóre wydane wcześniej rozwiązania dotyczące inteligentnych systemów pomiarowych wskazują jednak, że w priorytetowy sposób 
traktowana będzie modernizacja sieci elektroenergetycznych. Oznacza to, że w pierwszej kolejności do systemu elektroenergetycznego zaimplementowane zostaną sieciowe technologie informacyjne i komunikacyjne, dzięki którym nabędzie on cechy systemu inteligentnego, a dopiero następnym krokiem będzie unowocześnienie systemów pomiarowych u odbiorców tej energii ${ }^{30}$. Choć działania te wydają się racjonalne, to stoją w jawnej opozycji do realizacji zobowiązań unijnych dotyczących inteligentnych systemów pomiarowych. W związku $z$ tym cenna inicjatywa organów administracji rządowej w zakresie ISE nie zastąpi jednak starannej regulacji ustawowej, która ostatecznie rozstrzygnie kierunek działań wszystkich uczestników rynku.

Na koniec warto jeszcze wskazać, że zaproponowany przez ministra gospodarki projekt ustawy - Prawo energetyczne datowany na 8 października 2012 r., w art. 107 przesądzał o obowiązkowym wyposażeniu wszystkich odbiorców w inteligentne liczniki do 2020 r. Niestety, projekt ten nie doczekał się końca procesu legislacyjnego ${ }^{31}$. Wprowadzenie inteligentnych sieci wraz z towarzyszącym im rozwojem usług w sektorze telekomunikacyjnym niewątpliwie może stanowić swego rodzaju koło zamachowe dla unowocześnienia i rozwoju całej polskiej gospodarki, a także dla jeszcze ściślejszego powiązania dóbr i usług oferowanych w sektorze elektroenergetycznym oraz komunikacji elektronicznej.

\section{SMART GRIDS AS A PLATFORM FOR ENTREPRENEURS' INNOVATIVE ACTIVITY IN THE ENERGY SECTOR - LEGAL ISSUES}

\section{S u m mary}

This paper is an analysis of smart grids and smart metering concept under Polish energy law. The main focus is put on the innovative potential which will become available in the electricity market once the energy system in Poland is based on

\footnotetext{
${ }^{30}$ Stanowisko Prezesa URE z dnia 19 III 2015 r. w sprawie stosowania postanowień Stanowiska Prezesa URE w sprawie szczegółowych reguł regulacyjnych w zakresie stymulowania i kontroli wykonywania inwestycji w AMI z dnia 11 I 2013 r. oraz odpowiedź Prezesa URE na interpelację nr 32747 w sprawie infrastruktury licznikowej dla systemów AMI: http://www.ure.gov.pl/pl/stanowiska/6067,Stanowisko.html; http:// www.sejm.gov.pl/Sejm7.nsf/InterpelacjaTresc.xsp?key=0EEF700D (dostęp: 7 XII 2015).

${ }^{31}$ Mowa o pakiecie trzech ustaw: nowe Prawo energetyczne, Prawo gazowe i ustawa o odnawialnych źródłach energii, który Ministerstwo Gospodarki zaprezentowało 22 grudnia 2011 r., https://legislacja.rcl.gov.pl/projekt/19295/katalog/97872\#97872 (dostęp: 7 XII 2015).
} 
smart grids and when energy consumers are billed with the use of smart metering. In the first part of the paper, the concept of a smart grid and its innovative characteristics is presented. The main emphasis is put on cooperation between businesses operating in the energy sector and those in the IT sector. This innovative approach is indirectly determined by numerous EU legislative acts which set out trends and directions of development of the energy transmission system. The second part addresses the legal requirements of implementing a smart grid concept and looks at how this issue is understood the Polish regulatory authority and others bodies of central administration responsible for the energy sector. The paper ends with an identification of potential benefits arising from the implementation of smart grids and smart metering, which include: renewable energy resources, energy efficiency, energy security and the mechanism of demand side management. All these can contribute to the development of businesses involved in the energy sector and the development of a competitive electricity market in Poland.

Keywords: smart grids - advanced metering infrastructure - demand side management - competitive electricity market 